Univerzitet u Beogradu
Poljoprivredni fakultet
Institut za poljoprivrednu tehniku
Naučni časopis
POLJOPRIVREDNA TEHNIKA
Godina XLVI
Broj 4., 2021.
Strane: $41-48$

\title{
EFFECT OF SOLAR DRYING ON PROXIMATE COMPOSITION OF TWO VARIETIES OF GINGER RHIZOMES FOR BLANCHED AND UNBLANCHED TREATMENTS
}

\author{
Umunna Muofunanya Francis*1, Kayode Joshua Simonyan ${ }^{1}$ \\ ${ }^{1}$ Department of Agricultural and Bioresources Engineering, \\ Michael Okpara University of Agriculture, Umudike, Abia State, Nigeria
}

\begin{abstract}
Ginger (Zingiber officinale Roscoe) of two verities UG I ('Tafin-Giwa', a yellowish variety with plump rhizomes) and UG II ('Yatsun-Biri', a black or dark variety with small compact rhizomes), were analysed to identify its proximate composition. The effects of drying as a processing technique on ginger were investigated with respect to the proximate composition of the produce. The UG I and UG II were collected, sorted (whole, peeled and unpeeled) and (slice, peeled and unpeeled), and were subjected to Unblanched and Blanched $\left(50^{\circ} \mathrm{C}\right.$ at 3,6 and 9 min respectively) treatments and dried using solar dryer for a period of one month. The initial moisture content of UG I and UG II were $71.12 \%$ and $72.47 \%$ respectively, the final moisture content were reduced to $7.02 \%$ SUP (Unblanched) and 5.52\% SUP (Blanched at $9 \mathrm{~min}$ ) for UG I, while that of UG II were $4.82 \%$ SP (Unblanched) and 5.85\% WUP (Blanched at $3 \mathrm{~min}$ ). For Carbohydrate content, $61.38 \%$ was noted to be the lowest level at Unblanched (Whole peeled), and $68.37 \%$ indicates higher $\mathrm{CHO}$ content at Blanched $50^{\circ} \mathrm{C}$ at 9 min (Split Unpeeled) treatments for UG I samples. Similarly, for UG II, CHO's presence was low at $56.01 \%$ for Unblanched (Whole peeled) and high at $76.32 \%$ for Blanched on the temperature of $50^{\circ} \mathrm{C}$ at 9 min (Whole peeled) treatment. Ash content was observed to be low at $4.68 \%$ for Blanched $50^{\circ} \mathrm{C}$ at $3 \mathrm{~min}$ (Split Unpeeled) and high at $6.47 \%$ for Unblanched (Whole peeled) treatment for UG I samples, and 3.82\% low for Blanched on the temperature of $50^{\circ} \mathrm{C}$ at 9 min (Split peeled) with higher ash content of 7.69\% Unblanched (Split Unpeeled) treatment for UG II samples.
\end{abstract}

*Corresponding Author. E-mail: umunnamuofunanya25@gmail.com 
UG I and UG II samples determination for Crude fibre was observed at $4.64 \%$ for Blanched on the temperature of $50^{\circ} \mathrm{C}$ at $9 \mathrm{~min}$ (Whole Unpeeled) and $6.25 \%$ at Unblanched (Whole peeled) treatment, 3.72\% Blanched on the temperature of $50^{\circ} \mathrm{C}$ at $9 \mathrm{~min}$ (Split peeled) and 8.89\% at Unblanched (Whole Unpeeled) treatment, respectively. Determination of fat content, at UG I and UG II samples, it was observed that fat content are less at $7.41 \%$ for Blanched on the temperature of $50^{\circ} \mathrm{C}$ at $9 \mathrm{~min}$ (Whole Unpeeled) and $3.10 \%$ for Blanched on the temperature of $50^{\circ} \mathrm{C}$ at $9 \mathrm{~min}$ (Whole peeled) treatments, respectively. Higher fat content presences were observed at 9.00\% for Unblanched (Whole peeled) and $9.78 \%$ for Unblanched (Whole Unpeeled) treatments, respectively. Crude protein content shows that its presence was higher at $9.79 \%$ for Unblanched (Whole peeled) UG I and $11.75 \%$ for Unblanched (Whole Unpeeled) treatment UG II. While it was less at $8.32 \%$ Blanched on the temperature of $50^{\circ} \mathrm{C}$ at $9 \mathrm{~min}$ (Whole Unpeeled) UG I and $6.32 \%$ Blanched on the temperature of $50^{\circ} \mathrm{C}$ at $9 \mathrm{~min}$ (Split peeled) treatment UG II. The solar drying is effective in sufficient moisture removal and also for the enhancement of some nutritional composition of the produce (Ginger rhizoms).

Keywords: Drying, Ginger, proximate, composition, blanched, unblanched.

\section{INTRODUCTION}

Ginger (Zingiber officinale Roscoe) is an herbaceous perennial crop, grown as an annual crop for its spicy underground rhizomes. The plant has fibrous roots that emerge from the branched rhizomes. Closely grouped, unbranched, pseudostems or overial shoots are produced from the rhizomes. The pseudostems reach a height of $50-120 \mathrm{~cm}$. The simple, lanceolate, and smooth leaves are alternate and about $25 \mathrm{~cm}$ long. Ginger is asexually propagated from portions of the rhizome. The flowers of ginger are usually sterile and rarely set seed [1]. The shoot, leaf and the stem emit pleasant aroma. The anchorage roots are succulent and when squeezed exude appreciable fluid and emit aroma similar to the one from the other plants parts [2]; [3]. Over 25 varieties of ginger are grown worldwide. Varieties differ in the size of the rhizome, flower, aroma, pungency, colour and fiber content [1]. Nigerian ginger is darker in colour, min. in size and has more pungent taste when compared to others. Cochin ginger is usually larger, well scraped, contains more starch and breaks with a shorter fracture. African ginger is darker in colour, more pungent in taste and has less flavor than Jamaica ginger [4]. Two main varieties are grown in Nigeria. Umudike ginger I (UG I) known as the "black yellow ginger" and Umudike ginger II (UG II) known as the "black" ginger. The stem cluster of the yellow ginger is fat and robust, resembling the elephant's foot hence the name "Taffin-giwa". Similarly, the black ginger because of its shriveled and slander nature typical of the monkey's finger, it is called 'Yatsun biri" [2]; [3].

Fresh ginger contains $80.9 \%$ moisture, $2.3 \%$ protein, $0.9 \%$ fat, $1.2 \%$ minerals, $2.4 \%$ fibre and $12.3 \%$ carbohydrates $[4,5]$. The minerals present in ginger are iron, calcium and phosphorous. It also contains vitamin such as thiamine, riboflavin, niacin and vitamin C. The composition varies with the type, variety, agronomic conditions, curing methods, drying and storage conditions [5]. 
The branching fleshy rhizome composed of 40-60\% starch, 10-40\% yellow colour volatile oil responsible for its flavour and the remaining percentage for protein, mineral matter and fiber content [6]. Table 1 comprises of the nutrient/metabolic content of freshly harvested black and yellow ginger rhizome.

Table 1. Nutrient/Metabolic Constituents of Freshly Harvested Ginger Rhizome, [7]

\begin{tabular}{llll}
\hline S/N & Nutrient/Metabolite & $\begin{array}{c}\text { Yellow } \\
\text { (Tafin Giwa) }\end{array}$ & $\begin{array}{c}\text { Black } \\
\text { (Yatsun biri) }\end{array}$ \\
\hline 1 & Moisture (g/100g) & 78.00 & 80.90 \\
2 & Starch (g/100g dry weight) & 55.8 & 57.19 \\
3 & Total reducing sugars (g/100g dry weight) & 4.80 & 3.68 \\
4 & Crude protein (g/100g dry weight) & 17.15 & 10.15 \\
5 & True protein (g/100g dry weight) & 3.18 & 1.84 \\
6 & Total free amino acids (g/100g dry weight) & 5.27 & 4.38 \\
7 & Crude fiber (g/100g dry weight) & 3.24 & 4.77 \\
8 & Total lipids (g/100g dry weight) & 2.74 & 3.61 \\
9 & Total ash (g/100g dry weight) & 7.75 & 7.35 \\
10 & Acid -insoluble ash (g/100g dry weight) & 2.00 & 2.00 \\
11 & Total carotenoids (mg-carotene/100g dry weight) & 6.64 & 5.41 \\
12 & Ascorbic acid (g/100g dry weight) & 1.23 & 1.30 \\
13 & Ginger oleoresin (g/100g dry weight) & 5.61 & 6.26 \\
\hline
\end{tabular}

The main objective of this research is to determine the effect of Solar drying on proximate composition of two verities of ginger rhizomes (UG I and UG II), for Blanched and Unblanched treatment. Proximate analysis is referred to as the partitioning of compounds in a feed into six categories based on the chemical properties of the compounds. The six categories are moisture, ash, crude protein, crude lipid, crude fibre and nitrogen-free extracts (digestible carbohydrates).

\section{MATERIAL AND METHODS}

\section{Research Materials}

A costarred bowl (4 kg) of two ginger varieties, namely Umudike Ginger I and Umudike Ginger II (UG I and UG II), were purchased, respectively from the National Root Crop Research Institute, (NRCRI) Umudike, Abia State. $4 \mathrm{~kg}$ of UG I and UG II was cleaned and separated into groups. One of the groups was peeled and splitted with a sharp stainless steel knife The UG I and UG II split and whole, (peeled and unpeeled) was blanched with the aid of Electric water bath in the Soil and Water Laboratory, Department of Agricultural and Bioresources Engineering, Michael Okpara University of Agriculture, Umudike, Abia State. Ginger rhizomes were blanched (3, 6 and $9 \mathrm{~min}$.), on the temperature of $50^{\circ} \mathrm{C}$. Each group with various treatments were subjected to solar drying in sequence. The unblanched UG I and UG II split and whole, (peeled and unpeeled) was also subjected to solar drying for about a period of one month, before taken to the laboratory for proximate analysis. All treatments were done at $10 \mathrm{~mm}$ thickness of UG I and UG II rhizome. 


\section{Chemical analysis}

The dried UG I and UG II Samples were subjected to proximate analysis. The proximate composition of the samples UG I and UG II with various treatments, in respect to moisture, protein, fat, ash, fibre and carbohydrate percentage, were determined following the standard methods of association of official analytical chemists [8].

The UG I and UG II dried samples, were ground into fine powder, using a milling machine. The powdered samples were sieved through mesh $300 \mu \mathrm{m}$ sieve and stored in air-tight cellophane bag as stock sample in a refrigerator, until required for analysis [9]. Thermal drying method was used in the determination of moisture content of the samples [9]; [10].

\section{Moisture content determination}

Moisture was determined by the loss in weight of samples dried with solar and cabinet dryers respectively. The percentage moisture content was calculated by computing the loss in weight on drying as a fraction of the initial weight of sample used and multiplied by 100.

$$
\operatorname{Mc}(\%)=\frac{W o}{W i} \times 100
$$

Where $\mathrm{Wo}=$ loss in weight $(\mathrm{g})$ on drying and $\mathrm{Wi}=$ initial weight of sample $(\mathrm{g})$

\section{Crude fat content determination}

Crude fat content determination of the sample was done using soxhlet type of the direct solvent extraction method. Crude fat represents total fat in most samples. At the extraction end, the solvent was evaporated and the flask dried in the oven (at $60^{\circ} \mathrm{C}$ ). The flask was then cooled and reweighed. The percentage Crude fat (lipid) was calculated using the formula:

$$
\mathrm{CL}(\%)=\frac{M e x}{M g} \times 100
$$

Where Mex $=$ mass of extract $(\mathrm{g})$ and Ms $=$ mass of sample used $(\mathrm{g})$

\section{The Ash content determination}

The Ash content was determined using the ignition method by burning the sample in a muffle furnace at $600^{\circ} \mathrm{C}$ for $2 \mathrm{hrs}$. The percentage ash content was calculated using the formula:

$$
\text { Ash }(\%)=\frac{M a}{M s} \times 100
$$

Where $\mathrm{Ma}=$ mass of ash $(\mathrm{g})$ and $\mathrm{Ms}=$ mass of sample used $(\mathrm{g})$

\section{Determination of Crude protein}

Determination of Crude protein was done by determining the total organic nitrogen, using the macro-Kjeldhal method. This method determination digestion, distillation and titration. The technique determined the amino nitrogen of the sample, after which the total organic nitrogen was then calculated using the formula:

$$
\% T O N=\frac{T V \times N E \times T V d}{M s \times V d} \times 100
$$


Where:

$\mathrm{Tv}=$ Titre value, $\mathrm{NE}=\mathrm{mg}$ of nitrogen equivalent to molarity of acid,

$\mathrm{TVd}=$ total volume to which digest was diluted, Ms = mass of the sample $(\mathrm{g})$

$\mathrm{Vd}=$ volume of digest distilled

\section{Determination of Carbohydrate content}

Determination of Carbohydrate content of the sample was estimated by 'differences' [10]. In this, the sum of the percentages of all the other proximate components was subtracted from 100.

Total CHO $(\%)=100-(\%$ moisture $+\%$ crude protein $\%$ crude fat $+\%$ ash $)$

\section{Results}

\section{RESULTS AND DISCUSSION}

The results obtained in the study and results of the proximate analysis are presented in Table 2. It shows the variation range of values for Solar dried samples of UG I and UG II proximate analysis results for blanched and unblanched treatments respectively.

Table 2. Proximate (nutrients) contents of UG I and UG II varieties of Ginger rhizome, with various treatments for Solar dried samples

\begin{tabular}{|c|c|c|c|c|c|c|c|c|c|}
\hline \multicolumn{5}{|c|}{ UG I } & \multicolumn{5}{|c|}{ UG II } \\
\hline & WP & WUP & $\mathrm{SP}$ & SUP & UNBLANCHED & WP & WUP & SP & SUP \\
\hline$\% \mathrm{MC}$ & 7.13 & 7.10 & 7.06 & 7.02 & & 5.71 & 5.94 & 4.82 & 4.98 \\
\hline$\% \mathrm{CP}$ & 9.79 & 9.75 & 9.70 & 9.60 & & 8.44 & 11.75 & 7.97 & 11.54 \\
\hline$\%$ FAT & 9.00 & 8.95 & 8.95 & 8.86 & & 8.67 & 9.76 & 8.46 & 9.53 \\
\hline$\% \mathrm{CF}$ & 6.23 & 6.19 & 6.15 & 6.10 & & 7.08 & 8.89 & 7.05 & 8.80 \\
\hline$\% \mathrm{ASH}$ & 6.47 & 6.43 & 6.43 & 6.32 & & 6.22 & 7.63 & 6.23 & 7.69 \\
\hline \multirow[t]{2}{*}{$\% \mathrm{CHO}$} & 61.38 & 61.58 & 61.71 & 62.10 & & 63.88 & 56.01 & 65.47 & 57.46 \\
\hline & \multicolumn{9}{|c|}{ BLANCHED@3 min } \\
\hline$\% \mathrm{MC}$ & 6.09 & 6.28 & 6.15 & 6.35 & & 6.20 & 5.85 & 7.11 & 6.94 \\
\hline$\% \mathrm{CP}$ & 8.99 & 8.72 & 8.79 & 8.61 & & 6.65 & 6.97 & 6.57 & 7.90 \\
\hline$\%$ FAT & 8.17 & 7.73 & 7.95 & 7.96 & & 3.40 & 3.58 & 3.34 & 3.49 \\
\hline$\% \mathrm{CF}$ & 5.23 & 4.94 & 5.19 & 4.96 & & 3.98 & 4.32 & 3.94 & 4.26 \\
\hline$\% \mathrm{ASH}$ & 5.86 & 5.79 & 5.82 & 4.68 & & 4.17 & 4.36 & 4.08 & 4.39 \\
\hline \multirow[t]{2}{*}{$\% \mathrm{CHO}$} & 65.66 & 66.54 & 66.10 & 66.44 & & 75.60 & 74.92 & 74.94 & 73.02 \\
\hline & & \multicolumn{8}{|c|}{ BLANCHED @ 6 min } \\
\hline$\% \mathrm{MC}$ & 6.14 & 6.33 & 6.22 & 6.42 & & 6.31 & 5.99 & 7.26 & 7.14 \\
\hline$\% \mathrm{CP}$ & 8.76 & 8.57 & 8.64 & 8.48 & & 6.50 & 6.81 & 6.45 & 7.77 \\
\hline$\%$ FAT & 8.02 & 7.58 & 7.88 & 7.81 & & 3.27 & 3.46 & 3.22 & 3.31 \\
\hline$\% \mathrm{CF}$ & 5.00 & 4.77 & 4.96 & 4.83 & & 3.85 & 4.22 & 3.82 & 4.19 \\
\hline$\% \mathrm{ASH}$ & 5.72 & 5.55 & 5.68 & 5.54 & & 4.06 & 4.27 & 3.91 & 4.22 \\
\hline \multirow[t]{2}{*}{$\% \mathrm{CHO}$} & 66.36 & 67.20 & 66.62 & 66.92 & & 76.01 & 75.25 & 75.34 & 73.37 \\
\hline & \multicolumn{9}{|c|}{ BLANCHED @ 9 min } \\
\hline$\% \mathrm{MC}$ & 6.24 & 6.43 & 6.32 & 5.52 & & 6.47 & 6.15 & 7.36 & 7.27 \\
\hline$\% \mathrm{CP}$ & 8.62 & 8.46 & 8.51 & 8.32 & & 6.44 & 6.75 & 6.34 & 7.66 \\
\hline$\%$ FAT & 7.87 & 7.43 & 7.79 & 7.66 & & 3.12 & 3.34 & 3.16 & 3.15 \\
\hline$\% \mathrm{CF}$ & 4.87 & 4.64 & 4.83 & 4.70 & & 3.74 & 4.13 & 3.74 & 4.00 \\
\hline$\% \mathrm{ASH}$ & 5.58 & 5.41 & 5.54 & 5.40 & & 3.93 & 4.18 & 3.82 & 4.16 \\
\hline$\% \mathrm{CHO}$ & 66.82 & 67.63 & 67.01 & 68.37 & & 76.30 & 75.45 & 75.58 & 73.66 \\
\hline
\end{tabular}

Note: WP - Whole peeled; MC - Moisture content; WUP - Whole unpeeled; CP - Crude protein; $\mathrm{SP}$ - Split peeled; CF - Crude fibre; SUP - Split unpeeled and CHO - Carbohydrate 


\section{Discussions}

The proximate analysis experiment for both UG I and UG II, with various treatments, indicates higher values in percentage for unblanched UG I, and UG II. The results in the Table 2 show an increase in content of, ash, crude fiber, crude protein, fat, and carbohydrate. While the results for the blanched treatments of UG I and UG II show a reduction in percentage moisture content, ash content, crude fiber, crude protein, fat, and carbohydrate.

The initial moisture content of UG I and UG II were $71.12 \%$ and $72.47 \%$ respectively, the final moisture content were reduced to $7.02 \%$ SUP (Unblanched) and $5.52 \%$ SUP (Blanched at $9 \mathrm{~min}$ ) for UG I, while that of UG II were $4.82 \%$ SP (Unblanched) and $5.85 \%$ WUP (Blanched at $3 \mathrm{~min}$ ).

For Carbohydrate content, $61.38 \%$ was noted to be the lowest level at Unblanched (Whole peeled), and $68.37 \%$ indicates higher $\mathrm{CHO}$ content at Blanched at $50^{\circ} \mathrm{C}$ at $9 \mathrm{~min}$ (Split Unpeeled) treatments for UG I samples. Similarly, for UG II, CHO's presence was low at $56.01 \%$ for Unblanched (Whole peeled) and high at $76.32 \%$ for Blanched at $50^{\circ} \mathrm{C}$ at $9 \mathrm{~min}$ (Whole peeled) treatment.

Ash content was observed to be low at $4.68 \%$ for Blanched at the temperature of $50^{\circ} \mathrm{C}$ at $3 \mathrm{~min}$ (Split Unpeeled) and high at $6.47 \%$ for Unblanched (Whole peeled) treatment for UG I samples, and $3.82 \%$ low for Blanched at the temperature of $50^{\circ} \mathrm{C}$ at $9 \mathrm{~min}$ (Split peeled) with higher ash content of 7.69\% Unblanched (Split Unpeeled) treatment for UG II samples.

UG I and UG II samples determination for Crude fibre was observed at $4.64 \%$ for Blanched at the temperature of $50^{\circ} \mathrm{C}$ at 9 min (Whole Unpeeled) and $6.25 \%$ at Unblanched (Whole peeled) treatment, 3.72\% Blanched at the temperature of $50^{\circ} \mathrm{C}$ at $9 \mathrm{~min}$ (Split peeled) and $8.89 \%$ at Unblanched (Whole Unpeeled) treatment, respectively.

Determination of Fat content, at UG I and UG II samples, it was observed that Fat content are less at $7.41 \%$ for Blanched at $50^{\circ} \mathrm{C}$ at $9 \mathrm{~min}$ (Whole Unpeeled) and $3.10 \%$ for Blanched $50^{\circ} \mathrm{C}$ at $9 \mathrm{~min}$ (Whole peeled) treatments, respectively. Higher fat content presences were observed at $9.00 \%$ for Unblanched (Whole peeled) and $9.78 \%$ for Unblanched (Whole Unpeeled) treatments, respectively.

Crude protein content shows that its presence was higher at $9.79 \%$ for Unblanched (Whole peeled) UG I and $11.75 \%$ for Unblanched (Whole Unpeeled) treatment UG II. While it was less at $8.32 \%$ Blanched at the temperature of $50^{\circ} \mathrm{C}$ at $9 \mathrm{~min}$ (Whole Unpeeled) UG I and $6.32 \%$ Blanched at the temperature of $50^{\circ} \mathrm{C}$ at $9 \mathrm{~min}$ (Split peeled) treatment UG II. This study's findings agreed with earlier $r$ at the temperature of eports on ginger's proximate composition [9].

\section{CONCLUSIONS}

The results obtained in this research, can be concluded that the proximate composition for both UG I and UG II, indicates higher values in percentage for the unblanched treatment, which shows increased moisture content, ash content, crude fiber, crude protein, fat, and carbohydrate. 
While that of blanched treatments, shows a reduction in percentage moisture content, ash content, crude fiber, crude protein, fat, and carbohydrate. The solar drying is effective in sufficient moisture removal and also for the enhancement of some nutritional composition of the produce (Ginger rhizoms).

\title{
REFERENCES
}

[1]. Valenzuela, H. 2011. Farm and Forestry Production and Marketing Profile for Ginger (Zingiber officinale). Permanent Agriculture Resources (PAR), Holualoa, Hawai'I. http://agroforestry.net/scps

[2]. Okwuowulu, P.A. and Ene L.S. 1988. Exploited Plants: The Edible Ginger (Zingiber Officinale Rosc.). Proc. of the First National Ginger Workshop, Umudike. pp. 68-76.

[3]. Onu O.O and Simonyan K.J. (2015). Performance evaluation of a motorized ginger juice expression machine. African J. of Agr. Research (AJAR) Vol. 10(37), pp. 3662-3670.

[4]. Ghosh, A.K., Banerjee, S., Mullick, H.I. and Banerjee, J. 2011. Zingiber Officinale: A Natural gold. International Journal of Pharma and Bio sciences, 2(1).

[5]. Hoffman, T. 2007. Antimicrobial activity of some medicinal plants from India. Hawaii Medical Journal. 66: pp. 326- 327.

[6]. Simonyan, K.J., Jegede, K.M. and Lyocks, S.W. 2003. Development of a Motorized Ginger Slicer. Agr.Mechanization in Asia, Africa and Latin America 34(1), pp. 37-41.

[7]. Njoku, B.O., Mbanaso, E.N.A. and Asumugha, G.N. 1995. Ginger Production by Convectional and Tissue Culture Techniques. Dolf Madi Publishers, Owerri, Imo State.

[8]. AOAC 2002. Official methods of Analysis $17^{\text {th }}$ ed. Washington DC: Association of official Analytical Chemists.

[9]. Nwinuka, N.M., Ibeh, G.O. and Ekeke, G.I. 2005. Proximate Composition and Levels of some Toxicants in four commonly consumed spices. Journal of Appl. Sci.Environ. Mgt. 9 (1), pp. 150-155.

[10]. Ugwoke C.E.C and Nzekwe U. 2010. Phytochemistry and proximate composition of ginger (Zingiber Officinal) Journal of Pharmaceutical and Allied Sciences 7(5), pp. 1182-1187.

\section{UTICAJ SOLARNOG SUŠENJA NA PROSEČNI SASTAV DVA VARIJETETA KORENA ĐUMBIRA ZA BLANŠIRANE I NEBLANŠTANE TRETMANE}

\author{
Umunna Muofunanya Francis $^{1}$, Kayode Joshua Simonyan ${ }^{1}$ \\ ${ }^{1}$ Department of Agricultural and Bioresources Engineering, \\ Michael Okpara University of Agriculture, Umudike, Abia State, Nigeria
}

Sažetak: Đumbir (Zingiber officinale Roscoe) sa dva varijeteta: UG I (Tafin-Giva, žuta sorta sa izrazitim korenom) i UG II (Yatsun-biri, crna ili tamna sorta sa malim kompaktnim korenom) je analiziran kako bi se utvrdio njihov neposredni sastav.

Uticaj efekta sušenja kao tehnike prerade na koren đumbira ispitivani su obzirom na neposredni sastav proizvoda. 
Uzorci UG I i UG II su sakupljeni, sortirani (celi, oljušteni i neoljušten) i (isečen, oljušten i neoljušten) i podvrgnuti tretmanima neblanširani i blanširani (kuvanje na $50^{\circ} \mathrm{C}$ na 3,6 i 9 min.) i osušeni u solarnoj sušari u periodu od mesec dana.

Početni sadržaj vlage UG I i UG II iznosio je: 71,12\%, odnosno 72,47\%, a konačni sadržaj vlage smanjen je na 7,02\% SUP i 5,52\% SUP (blanširan do 9 min.) za UG I, dok je sadržaj UG II bio 4,82\% SP (neblanširano) i 5,85\% WUP (blanširano za 3 min.). Sadržaj ugljenih hidrata, $61,38 \%$ je zabeležen kao najniži nivo kod neblanširanog uzorka (ceo oljušten koren), a $68,37 \%$ ukazuje na veći sadržaj $\mathrm{CHO}$ u blanširanom uzorku na $50{ }^{\circ} \mathrm{C}$ za 9 minuta (isečeno, neoljušteno) za uzorke UG I.

Slično opisanom, za UG II, prisustvo CHO je bilo nisko od 56,01\% za neblanširani (celi, oljušten) i visoko od $76,32 \%$ za blanširan na $50^{\circ} \mathrm{C}$ za 9 min. (celi, oljušten). Uočeno da je sadržaj pepela nizak pri $4,68 \%$ za kuvani uzorak $50^{\circ} \mathrm{C}$ za 3 min. (isečen, neoljušten) i visok od 6,47\% za neblanširan (ceo koren, oljušten) tretman za uzorke UG I, i 3,82\% za blanširan $50^{\circ} \mathrm{C}$ za 9 minuta (isečen, oljušten) sa većim sadržajem pepela od 7,69\% tretmana neblanširan (neoljušten uzorak) za uzorke UG II.

Utvrđivanje sastava UG I i UG II uzoraka za sirova vlakna primećeno je na $4,64 \%$ za blanširane na $50^{\circ} \mathrm{C}$ za 9 min. (celi neoljuštni uzorci) i $6,25 \%$ za neblanširane (cele oljušteni uzorci) tretmane, $3,72 \%$ blanširane na $50^{\circ} \mathrm{C}$ za 9 min. (isečen, oljušten) i $8,89 \%$ na tretmanu nekivano (celo neljušteno).

Određivanje sadržaja masti, na uzorcima UG I i UG II, primećeno da je sadržaj masti manji kod 7,41\% za blanširane uzorke na $50^{\circ} \mathrm{C}$ u 9 min. (celi neoljšten) i $3,10 \%$ za blanširane $50^{\circ} \mathrm{C}$ u 9 minuta (celi oljušteni uzorci), respektivno. Prisustvo većeg sadržaja masti primećeno je za $9,00 \%$ za tretmane neblanširani (celi, oljušteni), odnosno $9,78 \%$ za tretmane neblanširani (celi, neoljšteni).

Sadržaj sirovih proteina pokazuje da je njihovo prisustvo bilo veće od $9,79 \%$ za neblanširani (celi, oljušteni uzorak) UG I I za $11,75 \%$ za neblanširani (celi neoljušten) tretman UG II. Iako je bilo manje na $8,32 \%$ blanširan $50^{\circ} \mathrm{C}$ za 9 min. (celi, neoljušten) UG I i $6,32 \%$ kuvani na $50^{\circ} \mathrm{C}$ za 9 min. (isečen, oljušten) kod tretmana UG II.

Sušenje na suncu je efikasno u dovoljnom uklanjanju vlage, a takođe i za poboljšanje nekih hranljivih sastojaka korena đumbira.

Ključne reči: Sušenje, đumbir, približan sastav, blanširan, neblanširan.

Prijavljen:

Submitted:

Ispravljen:

Revised:

Prihvaćen:

Accepted:
03.07.2021.

01.11.2021.

25.11.2021. 